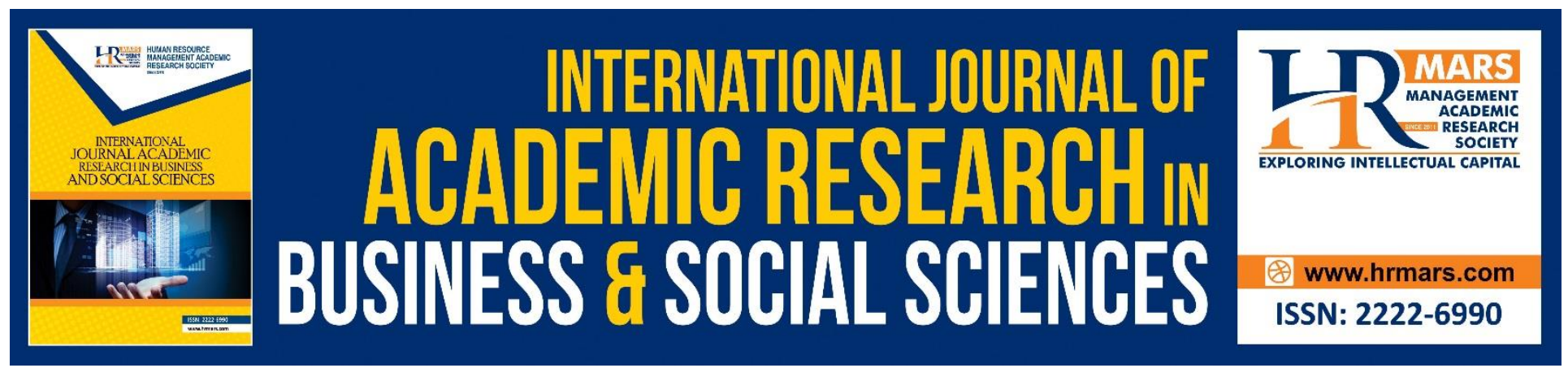

\title{
Comparative Framing Analysis of the 1malaysia Development Berhad Issue in Malaysian Mainstream Newspapers Post Ge-
} 14

\author{
Arman Ahmad, Akmar Hayati Ahmad Ghazali, Julia Wirza Mohd Zawawi, Siti \\ Aishah Hj Mohammad Razi
}

To Link this Article: http://dx.doi.org/10.6007/IJARBSS/v11-i15/10636

DOI:10.6007/IJARBSS/v11-i15/10636

Received: 09 May 2021, Revised: 10 June 2021, Accepted: 30 June 2021

Published Online: 21 July 2021

In-Text Citation: (Ahmad et al., 2021)

To Cite this Article: Ahmad, A., Ghazali, A. H. A., Zawawi, J. W. M., \& Razi, S. A. H. M. (2021). Comparative Framing Analysis of the 1malaysia Development Berhad Issue in Malaysian Mainstream Newspapers Post Ge-14. International Journal of Academic Research in Business and Social Sciences, 11(15), 77-92.

\section{Copyright: (C) 2021 The Author(s)}

Published by Human Resource Management Academic Research Society (www.hrmars.com)

This article is published under the Creative Commons Attribution (CC BY 4.0) license. Anyone may reproduce, distribute, translate and create derivative works of this article (for both commercial and non-commercial purposes), subject to full attribution to the original publication and authors. The full terms of this license may be seen at: http://creativecommons.org/licences/by/4.0/legalcode

Special Issue: Empowering Youth and Community Wellbeing for Sustainable Development, 2021, Pg. 77 - 92 http://hrmars.com/index.php/pages/detail/IJARBSS

Full Terms \& Conditions of access and use can be found at http://hrmars.com/index.php/pages/detail/publication-ethics 


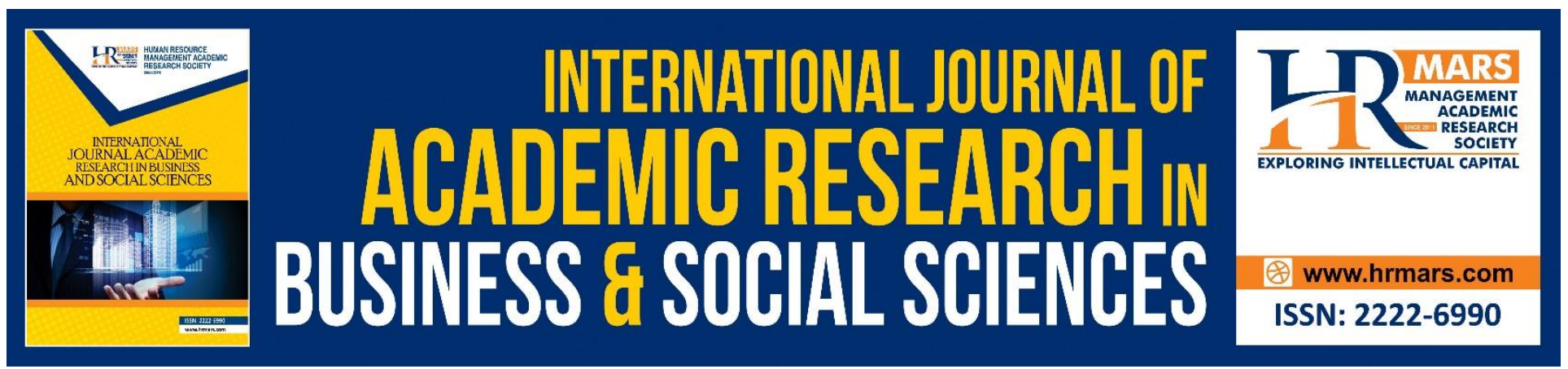

\title{
Comparative Framing Analysis of the 1malaysia Development Berhad Issue in Malaysian Mainstream Newspapers Post Ge-14
}

\author{
Arman Ahmad ${ }^{1}$, Akmar Hayati Ahmad Ghazali ${ }^{1,2}$, Julia Wirza \\ Mohd Zawawi ${ }^{1,2}$, Siti Aishah Hj Mohammad Razi ${ }^{2}$ \\ ${ }^{1}$ Institute for Social Science Studies, Universiti Putra Malaysia, 43400, UPM Serdang, \\ Selangor, Malaysia, ${ }^{2}$ Faculty of Modern Languages and Communication, Universiti Putra \\ Malaysia, 43400, UPM Serdang, Selangor, Malaysia
}

Email: akmar@upm.edu.my

\begin{abstract}
External factors such as political actors along with journalistic practice influence the news frames, selection of news sources and tone embedded in news. Following the landmark $14^{\text {th }}$ Malaysia General Election, political changes leading to the election also opened opportunities for reform in the Malaysian media landscape. Since the election, there have been calls for local scholars to revisit the new Malaysian media environment and re-evaluate the functions and roles of the media. To answer the question from the perspective of a framing theory framework, this paper will examine the contest for news frames in the coverage of Malaysian mainstream newspapers on the 1MDB scandal, the primary political issue covered in the run-up to GE14. Previous research posits that a winning party will have an edge over and will dominate frames in the media. The main factor for the presence of frames is the power of a political organisation that promotes frames. The idea that the new government will become the major frame setter is also reinforced by the indexing hypothesis. When the news explicitly slants, the politicians supported by the slant gain more influence and are empowered to do whatever they want without fear of being punished by voters. Those who are defeated in the framing competition become weaker, with less freedom to do and say as they please. The focus of this study then will be to understand how, in the aftermath of General Election 14 , has Malaysian mainstream media changed in its framing of the 1MDB issue after the loss of the ruling coalition. Specifically, it attempts to understand the relationship that political actors have on news frames, tone and use of sources on the 1MDB issue between the period before and after the 14th General Election, to discover if Malaysian mainstream media has started to evolve beyond the development model.
\end{abstract}

Keywords: News frames, 1MBD Issue, Frame Building, News Source, Tone, Political Actors 


\section{Introduction}

Millions of people turn to the mass media for their news needs every day, making it a centerpiece institution in democracies worldwide, including in Malaysia. An effective way for media news to shape public opinion is by framing issues and events in particular ways. Framing is widely considered one of several forms of media impacts, compelling, initiating and identifying goals and cueing as alternative strategies that can influence the public through media (Kinder, 2003; lyengar and Kinder, 1987).

The number of published framing studies (Scheufele and Iyengar, 2017) has increased significantly in recent years. This study has grown the awareness of how political attitudes and actions are shaped by how communicators choose to frame - or selectively portray and interpret - political issues that arise. Out of 418 international journals, local journals, expert publications and books between 1955 and 2016, and indicated by August, Oliveira, Tan, Smith, and Reinecke (2018) the most publications were related to framing, and studies involving ethnic conflicts, elections, political crises, and religious issues are quite prevalent in local journals. Even though framing research in the Malaysian context is substantial, the findings are relatively predictable because these research studies are on a small scale. They concluded the research studies with a "mainstream vs alternative media" ending and were restricted to simple content analysis. Most prior framing research focused on studying the frames in the news rather than studying the factors that add in the formation of such frames. On a broader scale, the query of how frames initially emerge in the news has not gained attention (Tandoc et.al, 2015).

The approach to the study of framing can be classified into two broad categories, according to Scheufele (1999). Frames are investigated as the dependent variable in the first group (the independent variables being all the organizational and contextual factors influencing frames). The second group studies the audience frames (frames in thought) as a dependent variable (influenced by the way the media frame issues). This approach to framing as a process was described as a continuum by de Vreese and elaborated in the Integrated Framing Process model.

Hänggli (2012) further expanded on the first step of the model by describing frame building as observing the progression of frames from political forces to journalists. The dependent variable in frames is mediated communication (i.e. frames in news content). The area which was ignored in the integrated model of framing was agreed by authors including Hänggli (2012), Dimitrova and Kostadinova (2013); Bolsen (2010); Snow et al. (2007); Borah (2011). As proof of the above, Borah (2011) found that only 2.3 per cent of the framing papers published between 1997 and 2007 concentrated on the frame-building process after a systematic review of literature.

In attempting to resolve this gap for the Malaysian context, this paper will examine the literature in the coverage of a contemporary issue, namely the financial scandal related to 1 Malaysia Development Berhad (1MBD) during and after the 14th General Election. The National Investment Fund was investigated for suspected malfeasance in July 2015, when authorities tracked US\$700 million from Malaysian Prime Minister Najib Razak's bank accounts. The Prime Minister and the Fund both refused any fraud, but the Malaysian Attorney General launched an inquiry into suspected corruption.

At the time of the scandal, 1MDB was RM42 billion in debt. The scandal was a major discussion point in Malaysian news due to its connection to former Prime Minister Najib Razak and spotlighted on mainstream media.

Given the poor performance of the Malaysian media in providing balanced news, and the known media hegemony by the ruling party (Hilley, 2001), there is a need to look at the factors that affect 
framing in the Malaysian context, and understanding what mechanisms produce the frames imbedded in the news Following the completion of the fourteenth general election, researchers should reassess the media's roles, particularly under the new government (Pyng et al., 2018). One of the things mentioned in the Pakatan Harapan manifesto was the Freedom of press. Mahathir promised to abolish several laws in one of his demonstrations if his party gets into the office (The Star, 3 April 2018). The Anti-Fake News Act, the Sedition Act, the Printing Presses and Publications Act were all included.

This study's primary focus is to examine the framing strategies and the tone of news adopted by mainstream newspapers on a contemporary political issue following Barisan Nasional's loss of power in the14th General Election. The election heralded an end to the UMNO hegemony in Malaysian politics, prompting a call for local scholars to revisit the new Malaysian media landscape. The functions of the media should be re-evaluated by scholars, particularly under the new regime (Pyng et al., 2018).

For this review paper, the selection criteria were undertaken through a search for the following keywords in the Google Scholar search engine for articles with the mention of: "1MDB", "1Malaysia Development Berhad", "General Election 14", "Malaysia", "News Framing", "Agenda Setting" among others. In addition, other keywords that were employed for the literature review included "FrameBuilding", "Political Actors", "Factors for Frame-Building, "Integrated Framing Process Model". A total of 58 articles were identified for the review.

\section{Framing}

Framing is recognised as the most widespread phenomenon in the communication research literature, and its origin is believed to be born from developments in cognitive psychology and anthropology (Van Gorp, 2007). Goffman (1974) presented the concept of framing, and its impressions can be observed in modern research work. Goffman was the first scholar who addressed the framing as a tool of communication and defined the framing as a "schemata of interpretation" which makes possible for the persons to "discover, recognize, identify, and label" the incidents and experiences of life (Goffman, 1974). According to McCombs and Shaw (1972), framing is secondarytier agenda-setting and thus tested the hypothesis that news media potentially influences the major issues highlighted to the public. They adopted the term "second-level agenda-setting" to describe the potential impacts of media coverage techniques and strategies on viewers' perception.

\section{Types of Frames}

According to Manheim (1994), news framing is categorized into three dimensions: visibility, valence, and frame genres. Visibility is considered as "the extent to which a nation receives news coverage about the prominence of a particular issue" (Liu, Wang, \& Zhao, 2010). The prominence is frequently assessed based on the publishing of the news in the newspaper, websites, television headlines, and other related news spreading mediums. Valence is related to the tone adopted or the news story and commentary related to the specific frames. Frame genres on the other hand, are seen as "journalistic schemes," which are usually summarized from existing studies of media discourse. An example is seen in the study of political news in which Semetko and Valkenburg (2000) identified five general news frames: conflict, human interest, attribution of responsibility, morality, and economic consequences.

De Vreese (2005) outlined two ways to approach framing studies in the news. The first method is inductive and prohibits making up any decision based on previously framed news in mind. Contrarily, 
the second approach is based on deductive reasoning, which deals with the frames that are protected and put into practice before the investigation (De Vreese, 2005).

Research on framing recognizes the difference between general and specific frames. The application of particular frames is limited to a specific topic or event. While the general frames are of broader scope, they can be applied with more flexibility on various physical, temporal, and cultural aspects (Kozman, 2017). General frames help evaluate the outcomes obtained from different research works carried out on different places on various topics. The theoretical body of generic frames requires the necessary materials to solidify the framing. In order to present the accurate and specific results, it requires the find and implementation of the particular frame, and this may complicate the task. Its effects could influence the public (Guenduez, Schedler, \& Ciocan, 2016).

\section{Generic Frames}

Semetko and Valkenburg (2000) conducted a large scale study and adopted content analysis to investigate 2,601 newspaper stories, and 1522 television news stories on the heads of European states in 1997. The outcomes of their research suggested five standard generic frames. News media can use some specific frames to convey their news to the audience, intentionally or unintentionally (Steimel, 2010). For example, Neuman, Just, and Crigler (1992) reviewed the four significant news frames that can be applied to multiple news contexts: the conflict, ethics, economic outcomes, and human impact frames. In their research work Valkenburg, Semetko, and De Vreese (1999), further included responsibility frame and human impact frame renamed as the human interest frame. A substantial number of researchers (An \& Gower, 2009; Cho \& Gower, 2006; D'Haenens \& De Lange, 2001; Schuck \& De Vreese, 2006; Semetko \& Valkenburg, 2000) have recognized the five frames and applied to them in their research work because the journalist across the globe extensively used these frames. The frames are specifically:

\section{Conflict}

The conflict frame is very prominent in the news media; it primarily highlights the different conflicts between individuals, groups, or organizations (Semetko \& Valkenburg, 2000). Cappella and Jamieson (1997) attempted to define the conflict frame traditionally, "the conflict frames usually depicts the differences between individuals, institutions, or countries." In the political coverage news, the conflict frames are criticized or presented in twisting political ideologies. While creating the news, the journalists compare them with competitive perspectives from the conflicts' basic frames (Schudson, 2001). According to McManus (1994), to present an unbiased and fair story of the journalists should consider different views on that particular topic.

The Western countries' journalists primarily focus on impartiality while they are reporting: therefore, the conflicts frames are prevalent in Western media. According to Neuman et al. (1992), Western journalists' principles of objectivity are the key factors to maintain impartiality and objectivity of the news. The media's conflict frames arise when the journalists criticize the political actors' perspectives over specific issues.

\section{Human Interest}

According to De Vreese (2005), the human interest frame is considered as the most frequently used generic news frame. Cho and Gower (2006), in their research study, proposed that the human interest frame significantly influences the human emotional responses. Semetko and Valkenburg (2000) stated that the human interest frame's objectives are to make the news more personal, emotional, 
and more appealing. A frame of human interest gives a human face and emotional feelings to the news of an event, problem, issue, and it enables the peoples to perceive the real picture of the news.

\section{Attribution of Responsibility}

This type of framing is related to the concept of perception as the application of political power. When taken into the context of news, it portrays the impression of power; it recognizes the political actors who compete to remain dominant (Entman, 1993). Schattschneider (1960) argues that the concept of power raises political conflicts that are not similar to the interfaith debate in which the competitors are agreed to talk on previously decided issues. The definition of the alternative is an excellent tool of power. The concepts signify attribution's objective as "frames build particular meanings according to the nature of issues and their emphasis, explanation, and exclusion (Carragee \& Roefs, 2004). Attribution framing can affect public opinion by invoking their specific thoughts; therefore, it is considered as the major influential factor of public opinion (lyengar, 1994). The importance of attribution has also been justified based on some recently conducted research studies in social cognition literature on several common model characteristics and information processing. lyengar (1996) conducted a research study on the effects of news framing on the attribution of responsibility regarding public issues; they revealed that responsibility is the primary factor determining the public's opinion regarding political issues. Therefore, it can be deduced that the individuals prefer to understand the political issues easily by recognizing the questions of responsibility, and their answers display their opinions about the issue (lyengar, 1994). According to Semetko and Valkenburg (2000), this frame can be defined as "attributing responsibility of a specific issue for a solution either governmental, individual, or group". Semetko and Valkenburg (2000) organized most frames used in the news into five categories: the responsibility frame, the conflict frame, the human interest frame, the morality frame, and the economic consequences frame.

\section{Morality}

"This frame portrays the problems, events, or issues while considering the morals, social norms, and religious implications (An \& Gower, 2009). According to Neuman et al. (1992), due to the journalistic ideology of impartiality, the frame of morality is frequently applied indirectly by giving journalists quotations and conclusions. The researchers suggested that the frame of morality is more effective while it evolves from their minds rather than from the news.

News presented in the contexts of ethical points of view is referred to as the terms of morality. The stories contain the social prescriptions about moral values, a reference to God, or other related religious beliefs of practices (Semetko \& Valkenburg, 2000). The journalistic views strictly follow the norms of objectivity; therefore, morality's framework is applied indirectly through quotations or research deductions (Neuman et al., 1992). The western media strictly follows the policy of publically refraining from following a particular deity, so references related to God are sporadic in their media coverage. On the contrary, norms and values are portrayed in the inhuman issues; the present scenario examples are war, refugee catastrophe, and famine. While discussing the media coverage crises, it was observed that the morality frame was not very often used as the other four frames, but it is used mostly used in a particular type of crisis. For example, the news covering the preventable crises is likely to be framed in the morality frame compared to the other crises related stories (An \& Gower, 2009). 


\section{Economic Consequences}

The economic frame is considered another typical frame used in the news Neuman et al. (1992). The economic or financial impacts of news are recognized as a matter of high interest. The economic consequences frame primarily emphasizes the economic and financial effects of an event, which has a significant value in the news. An and Gower (2009) proposed that this frame will present a picture of an event, problem, or issue concerning the economic consequences and how it economically affects an individual, group, organization, or country.

\section{New Sources}

When it comes to framing, there is an argument that news sources have more effect on the content of news than journalists do (Berkowitz \& Beach, 1993). The building blocks of a news article or report are statements from news sources, government representatives, company executives, organizational members, or even the man on the street who is interviewed by the news gatherer. According to Tichenor, Donohue, and Olien (1980), news, especially conflict news, consists of a mix of different news sources trying to advance their agendas and their perspective on issues.

The understanding that governmental sources account for the majority of sources in mainstream news media goes back to a landmark study by Sigal (1973) that found that these official sources were responsible for three-quarters of the news sources in mainstream The Washington Post and The New York Times newspapers. When the source is a head of government, such as a President or Prime Minister, frame salience was more pronounced, which was described by Hänggli (2012) as 'multiplication hypothesis'. Her study surmised that such a government head would have a special role in terms of frame frequency. Thus, the frames by the minister will have a higher receptiveness from the media compared to other actors.

\section{Tone}

The voice tone also distinguishes the quality of news coverage. The tone that frames the news is positive, neutral or negative (Brunken, 2006). Numerous research findings have shown that tones have various significant impacts on media coverage. Initially, tone impacts viewers to respond in certain ways about a specific issue. Earlier studies have shown that, if the content is presented negatively, individuals appear to have progressively negative views towards the subject (Brunken, 2006).

The significant impacts of tone on public opinion have been documented (Joslyn, 2003; Kim, Carvalho, \& Cooksey, 2007), Nelson, Clawson, and Oxley tolerance (1997), and topic recognition (McLeod \& Detenber, 1999) were also confirmed. Research indicates that the tone of the voice is emotionally rich in the first few days after the incident but is disassociated and contextualized with time (Gortner \& Pennebaker, 2003). Specific frames have been found to be representative of the 'good' or 'evil' dichotomy and to have positive or negative elements indirectly, or both (De Vreese \& Boomgaarden, 2003).

\section{Factors that Influence Frame Building}

Frame building is a process shaped by various factors that are both internal and external to journalism (Gitlin, 2003). Framing factors include political actors' strategic communicative behavior, journalistic norms and habits, reporters' schemes, political philosophy and cultural interpretations and perspectives (De Vreese, 2005). The importance of factors internal to journalism, particularly the role of media staff in news framing, has been recognized by earlier research. In shaping news frames, 
most existing frame-building research focused on internal variables, such as journalistic habits (Gans, 1979; Gitlin, 2003). Consequently, it was assumed that internal influences were more powerful in influencing media frames than external ones, such as political actors. It was found that news was affected by the socialization and behaviors of media workers and media routines (Gitlin, 1980). On the other hand, the frame building process also had constant interaction between journalists and elites (Snow \& Benford, 1992) and social movements (Gans, 1979).

Frame building refers to factors that affect the structural attributes of news frames. The outcomes of frame creation are the frames manifested in the text (Vreese, 2005). Understanding how frames are created makes it easier to interpret the resulting news frames (Shoemaker \& Reese, 1996). Journalist framing was conceptualized by Scheufele and Scheufele (2010) as a continuum between passively passing on interpretations given by other actors (frame sending) and supplying the audience with individual interpretations of a situation by the journalist (frame setting) (Shoemaker \& Reese, 1996). The influence that some actors has been recognised as important in terms of framing. When it comes to policy-related topics, elected officials are always the primary news coverage source. This focus on political officials has resulted in issues being presented by them. Since government officials monitor the flow of information and decide if a policy announcement should be made public, government frames are likely to guide media frames of news (Yang, 2003).

In a frame-building process, political actors such as elites, government leaders, and interest groups are actively engaged in pushing frames that support their interests. Journalistic practices are under pressure from authorities, as previously acknowledged; different studies have found growing evidence of pressure from interest groups and policymakers who have affected news framing (Andsager, 2000; Nisbet, Brossard, \& Kroepsch, 2003).

The idea that national political elites influence media framing is also reinforced by framing studies. The political administration, other elites, the media, and the public all contribute to the creation of news frames, but not to the same degree, according to Entman's 'cascading network activation model'. Entman (2004) also suggests that 'highlights packed into selective, framed messages' appear to be what passes through the cascade.

\section{The Effect that Political Actors have on Framing}

"The media is often referred to as the "Fourth Estate," although it is not embodied in the law as the other three governments, namely legislative, executive and judicial powers, which have a legal definition of their roles, obligations and limits and their relationship with the other institutions concerned (Hänggli \& Kriesi, 2010). Press freedom laws generally govern the media, freedom of opinion and speech, and information freedom. In democratic systems, content from the media is selfregulated. Compared to the other three jurisdictions, as long as they operate under the law, there are no institutionalized regulation structures for the media system (Brants et al., 2010). Along with law and ethics, the media continually practices its stories and routine operations. Non-democratic governments use the news media to maintain their dominance as one their many tools to retain power. Only unusual situations may unleash self-imposed restrictions on the media, such as unprecedented incidents, significant policy failures or scandals, or rapidly evolving power relationships, after which underreported perceptions of events can be implemented.

Some of the assertions that exist are the hierarchy of official and semi-official political actors who push news frames down to news organizations and the public. In his Cascade Activation model, Entman (2010) described this, describing a cascade of news frames from the White House to the average person. A multi-phase mechanism involving the flow of frames from political actors to 
journalists, and journalists to electorates, is basically the chain of contact from political actors to voters. Frame building is the step between the political actors and the journalists (Scheufele \& Scheufele, 2010). At times, counter-frames from secondary social or political outlets will increase, such as during disputes in official circles or mid-level sources, which can help drive up counter-frames (Entman, 2003). In framing, political instability is also a factor. When there is no policy on a specific issue, or there is no political consensus in the government, the media will appear to cover different aspects and represent the debate among political élites from various angles. The news media prefer to act following the official stance if political leaders exchange views on policy about a problem. The official strategy is unlikely to be modified even in the unprecedented event of critical media attention. As the media's primary source, the government will use instruments under its control and credibility to shape media coverage (Robinson, 2002). In general, the result of this process is the 'semiindependent press', which can be described as a dependent press that has 'moments of relative freedom' (Brants et al., 2010).

The explanation of why the media relies on officials is primarily due to work schedules for newsgathering. Reliable sources, which are essential for daily operations, give constant, instant access to journalists. The positions of the media outlets may, therefore, represent the positions taken by the officials. This notion supports the theory of media hegemony in which newspapers, television and other media transmit official propaganda (Herman and Chomsky 1988). The media are seen as passive transmission belts by the reliance on officials. It underpins the value of the media as autonomous political actors.

Usually, the most interesting news reports are related to the state or power elite of a country. In this manner, news media has to establish a better association with prominent politicians and advisers to their press. It must act as a win-win scenario to function properly. The journalist will not keep covering the politician if the politician is reluctant to provide enough details on a specific subject.

The desire to make others do what they really want has been the most primitive concept of power (Nagel, 1975). Thus, "telling people what to think" is how one influences politics in a competitive political system. The conceptualization of the relationship between political actors and the media through an actor-centered model of the democratic establishment was proposed by (Wolfsfeld \& Gadi, 1997). The approach by Wolfsfeld to understand the position of the news media is to perceive it as part of more significant competition between political rivals to influence the national agenda and to interpret particular policy issues to the public.

These arguments lend support to the notion that the main factor in frame presence is the influence of the political organizations that support a frame. This theory is based on several research demonstrating that the media's coverage to the more powerful actors is more prominent and that powerful actors have exclusive media exposure. (Entman, 2007; Gans, 1979; Wolfsfeld, 1997). The argument also reinforces the 'indexing hypothesis,' which assumes that 'the spectrum of voices and opinions articulated in a mainstream government discussion about a given topic' would be 'indexed by the mass media professionals' (Bennett, 1990). Consequently, the less influential actors' frames would be less likely to be supported. This is called the theory of power bias. In the context of the media's critical role to reach more people, the battle for publicity and the relevance of political issues is also a competition to handle the media narrative and structure the news.

\section{Malaysian Mainstream Media and Relationship with the Previous Government}

Over the years, there has been a great deal of literature that supports the assertion that Malaysian mainstream media lacks freedom. The internet has brought some liberation, but most newspapers 
that existed before the advent of the internet are still in operation. The ownership patterns of these newspapers remain the same, and according to Kenyon and Marjoribanks (2007), the mainstream media has existed in its current form since the British Colonial administration. The three English newspapers, two Malay dailies, five Chinese dailies, and two Tamil dailies continue to operate today. Before GE14, Malaysia's media ownership was still highly concentrated, with the government being a major stakeholder. The News Straits Times, Berita Harian and Harian Metro were owned indirectly through proxies of Umno - a political party in Malaysia (Sentinel, 2010). Scholars such as Yang (2003) say that mainstream media companies are controlled by the ruling party through ownership and legislation, and are bent on producing political news favoring the government. According to Lumsden and Morgan (2017), Malaysian mainstream newspapers and four main television stations are owned by Barisan Nasional (B.N.) or controlled by corporations affiliated with it. Hence, with this arrangement, the mainstream media consistently frames Barisan Nasional news positively.

Mainstream Media and Relationship with New Government

One of the key points on the manifesto for the new Pakatan Harapan government which came into power following the 14th Malaysian General Election was to allow for greater press freedom. During his inauguration ceremony, the new Minister of Malaysian Communications and Multimedia Gobind Singh Deo stated that the media should have more independence in their coverage and criticism of the government. In their manifesto of the election, Pakatan Harapan had committed to ensuring that the press had the freedom to serve as an administrative check and balance. The manifesto also proclaimed the P.H. administration would step up independence and professionalism for such organizations as Radio Television Malaysia and Bernama national news agency. The P.H. government also pledged to create a media council comprising media personalities, establishing and enforcing a code of journalism ethics and acting as a public complaint hisbah agency (ombudsman). The party also vowed to abolish the Sedition Act 1948, Crime Prevention Act1959, the University Colleges Act 1971, and the Printing Press and Publications Act 1984. Democracy relies on the existence of robust and unbiased media.

Mustafa (2016) argued that democracy requires citizens' right to free speech in the public domain from a communication viewpoint. "It allows them to exercise their right to enter into discussions or debates and to express critical views collectively relating to the wellbeing of society, which is vital for citizens' involvement in decision-making in the stable democracy" " (Mustafa, 2016). However, scholars have long argued that this function is non-existent in the Malaysian media landscape. The control of the mainstreams media by the ruling party via ownerships and legislation has continuously been criticized by scholars, who opined that it freedom of opinion (Ahmad \& Othman, 2014; Anuar, 2014; Sani \& Azizuddin, 2014). Anuar (2003) argued that the biased reports not only distort the information to the citizens but also affected the process of nation-building due to the lack of genuine and constructive criticisms towards the government and its developmental policies and projects.

As far as up to the $13^{\text {th }}$ General Election, the media still played their roles as usual (Baharin et al. 2020). Traditional media outlets are used to target opposition groups, while independent media outlets offer a voice for opposing viewpoints. Following the general election in 2008, the realm of political news publishing in Malaysia has barely changed.

\section{The Malaysian Mainstream Media post-GE14}

Reporters without Borders documented a noteworthy improvement in Malaysia's press freedom (Funston, 2018). In 2018, Malaysia rank improved to 145, and improved a further 22 places to 123 for 2019. RSF identified a much more comfortable general atmosphere for journalists; self-censorship 
has significantly declined; print media are now providing a more comprehensive and balanced spectrum of points of view, including support for Prime Minister Mahathir Mohamad's new ruling coalition and support for the now opposing old coalition government. Following the announcement of GE14 results, the narrative taken on by the new government has been on reform for the mainstream media.

However, research needs to be done to test whether measurable changes have been made in news framing.

\section{Framing Studies}

There has been minimal consensus on how to identify frames in the news. Thus, framing research shares little conceptual ground with most studies drawing on tentative working definitions or operational definitions of frames designed particularly for the study(De Vreese, 2005). In general, news framing research specifically designed to be inductive with no prior news frame in mind (Neuman et al., 1992). During the analysis process, the frames are teased out from the material. In the news framing deductive research, the approach has also been employed and uses defined and prior operationalized frames to investigate. The studies with an inductive approach have been criticized for relying on too small a sample and being difficult to replicate (Hertog \& McLeod, 2001). In connection with operationalization, news framing may follow either the issue-specific or generic frame route. The generic frame mainly includes episodic vs. thematic framing (lyengar, 1990), human interest, strategic game frame, conflict, responsibility, economic consequences, and morality frames (Semetko \& Valkenburg, 2000). The frames and framing research has plenteous literature on frames, and framing research has provided plenteous literature, drawing from diverse fields. The interdisciplinary nature of framing research has led to the varied definitions of frames and the employment of different methodologies (Borah, 2011).

\section{Framing of 1MDB Financial Scandal}

Ting et al (2020) conducted a framing analysis of news frames on 1MDB used by The Star and Malaysiakini and concluded that there was a strong episodic orientation in the articles of both newspapers. This indicate careful approach to the controversial topics which implicated influential politicians and top officers in the government, which the authors attributed to a landscape in which laws governing press freedom may cause the halt of printing permits. The Star had a mix of positive, negative, and neutral 1MDB-related articles before the change of government, but Malaysiakini articles were more negative. Both newspapers took a constructive approach in reporting on 1MDB during the Pakatan Harapan administration, concentrating on actions to address the financial scandal.

From a standpoint of internal factors of framing, interviews with several personnel of Malaysian media organizations at Astro Awani, Utusan Malaysia, TV3, and, The China Press (Nazmi \& Rahim, 2016) revealed that the national interest continues to be relevant in Malaysian media circles in the reporting of $1 M D B$. The journalists interviewed stated that such concerns about 1MDB, for example, must be carefully handled since it is a state-owned and can affect the confidence of foreign investors.

\section{Theoretical Framework}

The theoretical framework of this research study is the framing theory based on De Vreese's (2005) Integrated Framing Process Model. 
INTERNATIONAL JOURNAL OF ACADEMIC RESEARCH IN BUSINESS AND SOCIAL SCIENCES

Vol. 11, No. 15, Empowering Youth and Community Wellbeing for Sustainable Development, 2021, E-ISSN: 2222-6990 @ 2020 HRMARS
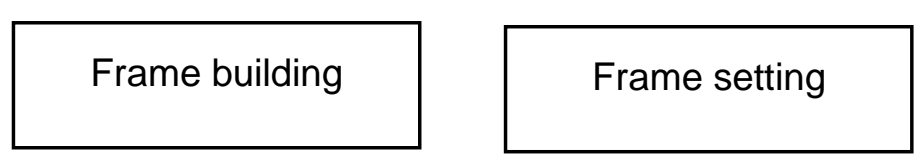

\begin{tabular}{|c|c|c|}
\hline $\begin{array}{l}\text { Framing in the } \\
\text { newsroom } \\
\text { - } \quad \text { Internal factors } \\
\text { (editorial policies, } \\
\text { news values) } \\
\text { - External factors } \\
\text { (political actors) }\end{array}$ & $\begin{array}{l}\text { Frames in the } \\
\text { news } \\
\text { - Issues-specific } \\
\text { frame } \\
\text { - Generic frame }\end{array}$ & $\begin{array}{ll} & \text { Framing effects } \\
\text { - } & \text { Information } \\
& \text { processing effects } \\
\text { - } & \text { Attitudinal effects } \\
- & \text { Behavioural } \\
& \text { effects }\end{array}$ \\
\hline
\end{tabular}

Figure 1.1: An Integrated Framing Process Model (Source: de Vreese, 2005)

In this model, frame-building is theorized as the first step of a process which includes frame-building, frame-setting and individual and societal level consequences of framing. The factors that affect the structural qualities of news frames are referred to as frame-building factors. These factors come in the form of internal factors in journalism shape the way journalists and news organisations frame issues. Or external influences, which are equally significant. Journalists and elites (Gans, 1979; Tuchman, 1978) and social movements (Cooper, 2002; Snow \& Benford, 1992) engage in a constant relationship during the frame-building period. The frames that appear in the news, whether issue specific or generic are the product of the frame building process. The second step, or frame setting stage results in the framing effects, whether in terms of information processing effects, attitudinal effects or behavioural effects.

\section{Conceptual Framework}

The study suggests investigating the link between the various factors for framing and discover their relationship with the frames imbedded in the news for the 1MDB issue in the first stage of Integrated Framing Process model, or the frame-building process. Hanggli's Power Bias Hypothesis states that weak political actors will not be covered and the key factor for frame presence is the power of the political organizations that promote a frame. Are powerful political actors still the main factor of framing in Malaysia post GE-14? Research needs to be done to test this. 


\section{GE 14}

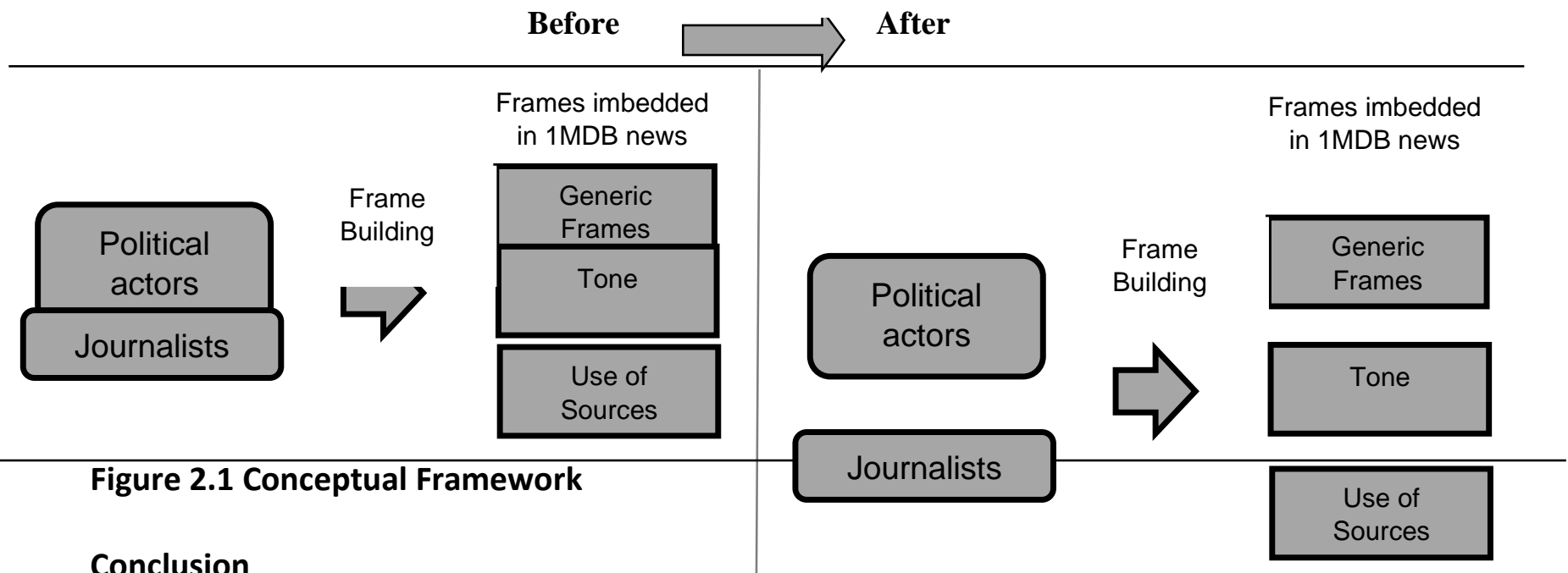

\section{usion}

Frames profoundly influence how people view the world by shaping how it is perceived (Holody, 2006). Internal factors influencing the frame building mechanism as in daily newsroom routines, it is found that their newsroom culture binds media staff in covering news. External factors also play a vital role in frame building; therefore, they should not be neglected in the frame-building process. The political actors, system, environment, and current issues are the external factors which affect the news framing. Media frames do not evolve suddenly but are formed gradually by the internal and external factors through a competitive process. The earlier mentioned example explains that all the participants of a particular issue have explicitly constituted important frames from which a specific aspect of the story can be developed. Framing could also play an essential role in acquiring the public support which is very beneficial in the accomplishment of political and communicative objectives, and news sources are must be according to the previously designed strategies. The frames should strictly follow the stories of their preferences; moreover, the framed news stories are aligned with their desired framing. The news sources are the primary source which influences the whole frame building process, but this does not imply that journalist only plays the role of a "message transmitter" for the news sources. The journalist is not only the persons who deliver the information or put forward the news, but they play an essential role in selecting and compiling the noteworthy news material before the printing, the influence of the journalists on the news framing has been proved to be very useful in the framing of the news stories. Therefore, news sources or the media workers cannot assert that they are the sole owner of the news frame presented on the media. Thus, it is evident that the news frame presented on the media is the influence of the external and internal factors on news resources and media workers. This research can help provide evidence on whether there have been changes in the media landscape following GE14, and set a benchmark to measure improvements in democracy of Malaysian press.

\section{References}

Ahmad, M. K., \& Othman, M. B. (2014). General election and the enigma of free press in Malaysia. Procedia-Social and Behavioral Sciences, 155, 547-552.

An, S.-K., \& Gower, K. K. (2009). How do the news media frame crises? A content analysis of crisis news coverage. Public Relations Review, 35(2), 107-112. 
Anuar, M. K. (2003). The role of Malaysia's mainstream press in the 1999 general election. New Politics in Malaysia. Singapore: ISEAS, 53-65.

Anuar, M. K. (2014). Defining democratic discourses: the mainstream press. In Democracy in Malaysia (pp. 152-178): Routledge.

Bennett, W. L. (1992). The governing crisis: Media, money, and marketing in American elections: St. Martin's Press New York.

Berkowitz, D., \& Beach, D. W. (1993). News sources and news context: The effect of routine news, conflict and proximity. Journalism Quarterly, 70(1), 4-12.

Borah, P. (2011). Conceptual issues in framing theory: A systematic examination of a decade's literature. Journal of communication, 61(2), 246-263.

Boydstun, A. (2014). Dallas Card, Justin H. Gross, Philip Resnik, and Noah A. Smith.

Brants, K., De Vreese, C., Möller, J., \& Van Praag, P. (2010). The real spiral of cynicism? Symbiosis and mistrust between politicians and journalists. The international journal of press/politics, 15(1), 25-40.

Brunken, B. L. (2006). Hurricane Katrina: A content analysis of media framing, attribute agenda setting, and tone of government response.

Cappella, J. N., \& Jamieson, K. H. (1997). Spiral of cynicism: The press and the public good: Oxford University Press.

Carragee, K. M., \& Roefs, W. (2004). The neglect of power in recent framing research. Journal of communication, 54(2), 214-233.

Cho, S. H., \& Gower, K. K. (2006). Framing effect on the public's response to crisis: Human interest frame and crisis type influencing responsibility and blame. Public Relations Review, 32(4), 420422.

D'Haenens, L., \& De Lange, M. (2001). Framing of asylum seekers in Dutch regional newspapers. Media, Culture \& Society, 23(6), 847-860.

De Vreese, \& Boomgaarden, H. (2003). Valenced news frames and public support for the EU. Communications, 28(4), 361-381.

De Vreese, C. H. (2005). News framing: Theory and typology. Information design journal \& document design, 13(1).

Entman, R. M. (1993). Framing: Toward clarification of a fractured paradigm.

Funston, J. (2018). Malaysia's 14th General Election (GE14)-The Contest for the Malay Electorate. Journal of Current Southeast Asian Affairs, 37(3), 57-83.

Gans, H. J. (1979). Symbolic ethnicity: The future of ethnic groups and cultures in America. Ethnic and racial studies, 2(1), 1-20.

Gitlin, T. (2003). The whole world is watching: Mass media in the making and unmaking of the new left: Univ of California Press.

Goffman, E. (1974). Frame analysis: An essay on the organization of experience: Harvard University Press.

Gortner, E.-M., \& Pennebaker, J. W. (2003). The archival anatomy of a disaster: Media coverage and community-wide health effects of the Texas A\&M bonfire tragedy. Journal of Social and Clinical Psychology, 22(5), 580-603.

Guenduez, A. A., Schedler, K., \& Ciocan, D. (2016). Generic frames and tonality: Mapping a polarizing issue in a multifaceted context. European journal of communication, 31(5), 584-599.

Hänggli, R., \& Kriesi, H. (2010). Political framing strategies and their impact on media framing in a Swiss direct-democratic campaign. Political Communication, 27(2), 141-157. 
Hertog, J. K., \& McLeod, D. M. (2001). A multiperspectival approach to framing analysis: A field guide. In Framing public life (pp. 157-178): Routledge.

Holody, K. J. (2006). Framing death: The use of frames in newspaper coverage of and press releases about death with dignity. Virginia Tech,

lyengar, S. (1990). Framing responsibility for political issues: The case of poverty. Political behavior, 12(1), 19-40.

lyengar, S. (1994). Is anyone responsible?: How television frames political issues: University of Chicago Press.

Iyengar, S. (1996). Framing responsibility for political issues. The Annals of the American Academy of Political and Social Science, 546(1), 59-70.

Joslyn, M. R. (2003). Framing the Lewinsky Affair: Third-Person Judgments by Scandal Frame. Political Psychology, 24(4), 829-844.

Kenyon, A. T., \& Marjoribanks, T. (2007). Transforming media markets: The cases of Malaysia and Singapore. Australian Journal of Emerging Technologies and Society, 5(2), 103-118.

Kim, S.-H., Carvalho, J. P., \& Cooksey, C. E. (2007). Exploring the effects of negative publicity: News coverage and public perceptions of a university. Public Relations Review, 33(2), 233-235.

Kozman, C. (2017). Measuring issue-specific and generic frames in the media's coverage of the steroids issue in baseball. Journalism Practice, 11(6), 777-797.

Liebler, C. M., \& Bendix, J. (1996). Old-growth forests on network news: News sources and the framing of an environmental controversy. Journalism \& Mass Communication Quarterly, 73(1), 53-65.

Liu, Y. J., Wang, M. C., \& Zhao, L. (2010). Narrow framing: Professions, sophistication, and experience. Journal of Futures Markets: Futures, Options, and Other Derivative Products, 30(3), 203-229.

Lumsden, K., \& Morgan, H. (2017). Media framing of trolling and online abuse: silencing strategies, symbolic violence, and victim blaming. Feminist Media Studies, 17(6), 926-940.

Manheim, J. B. (1994). Strategic public diplomacy and American foreign policy: The evolution of influence: Oxford University Press New York.

McCombs, M. E., \& Shaw, D. L. (1972). The agenda-setting function of mass media. Public opinion quarterly, 36(2), 176-187.

McLeod, D. M., \& Detenber, B. H. (1999). Framing effects of television news coverage of social protest. Journal of communication, 49(3), 3-23.

McManus, J. H. (1994). Market-driven journalism: Let the citizen beware? : Sage Publications.

Nazmi, S., \& Rahim, M. H. A. (2016). The Reporting on the 1Malaysia Development Berhad (1mdb) Crisis and Implication on Efficacy of Economic and Financial News Reporting in Malaysia. Advances in Social Sciences Research Journal, 3(10) 12-21.

Neuman, W. R., Just, M. R., \& Crigler, A. N. (1992). Common knowledge: News and the construction of political meaning: University of Chicago Press.

Paletz, D. L., \& Entman, R. M. (1981). Media power politics: Free Press.

Sani, M., \& Azizuddin, M. (2014). The Social Media Election in Malaysia: The 13th General Election in 2013. Kajian Malaysia: Journal of Malaysian Studies, 32.

Schattschneider, E. E. (1960). Party government: Transaction Publishers.

Scheufele, B., \& Scheufele, D. A. (2010). Of Spreading Activation, Applicability, and Schemas Conceptual Distinctions and Their Operational Implications. P. D’Angelo \& JA Kuypers, Doing News Framing Analysis: Empirical and Theoretical Perspectives. New York: Routledge. 
Schuck, A. R., \& De Vreese, C. H. (2006). Between risk and opportunity: News framing and its effects on public support for EU enlargement. European journal of communication, 21(1), 5-32.

Schudson, M. (2001). The objectivity norm in American journalism. Journalism, 2(2), 149-170.

Semetko, H. A., \& Valkenburg, P. M. (2000). Framing European politics: A content analysis of press and television news. Journal of communication, 50(2), 93-109.

Sentinel, A. (2010). Malaysia's brain drain. Url: http://www. asiasentinel. com/index. php.

Shoemaker, P. J., \& Reese, S. D. (1996). Mediating the message: White Plains, NY: Longman.

Snow, D. A., \& Benford, R. D. (1992). Master frames and cycles of protest. Frontiers in social movement theory, 133, 155.

Steimel, S. J. (2010). Refugees as people: The portrayal of refugees in American human interest stories. Journal of Refugee Studies, 23(2), 219-237.

Tichenor, P. J., Donohue, G. A., \& Olien, C. N. (1980). Community conflict and the press (Vol. 8): SAGE Publications, Incorporated.

Valkenburg, P. M., Semetko, H. A., \& De Vreese, C. H. (1999). The effects of news frames on readers' thoughts and recall. Communication research, 26(5), 550-569.

Van Gorp, B. (2007). The constructionist approach to framing: Bringing culture back in. Journal of communication, 57(1), 60-78.

Wolfsfeld, G., \& Gadi, W. (1997). Media and political conflict: News from the Middle East: Cambridge University Press.

Yang, J. (2003). Framing the NATO air strikes on Kosovo across countries: Comparison of Chinese and US newspaper coverage. Gazette (Leiden, Netherlands), 65(3), 231-249. 